\title{
Transnational carceral capitalism and private paramilitaries in Xinjiang and beyond $^{*}$
}

\author{
Gerald Roche
}

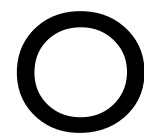

n 22 January 2019, the innocuously named Frontier Services

Group (FSG) announced plans to open a 'training centre' in Tumxuk city in Xinjiang (Shepherd 2019), the 'autonomous region' where hundreds of thousands of people have been held in concentration camps. Although the company has distanced itself from these plans and removed mention of it from its website (Ordonez 2019), this announcement highlighted a vital and underexplored element in the story of Xinjiang's camps: the role of private paramilitary companies and transnational circulations.

Frontier Services Group is a private security firm run by Blackwater founder, Erik Prince (Ciralsky 2009). And although Prince publicly expressed surprise at the 22 January announcement, FSG was in fact already deeply embedded in Xinjiang well before then (Stevenson and Buckley 2019). The company first announced plans to open an office in Xinjiang in March 2017 (Fan 2017). And in November of that year, it appointed Lü Chaohai as head of its northwestern regional operations (Bloomberg 2019; FSG 2017). Previously, Lü was the vice-president of the Xinjiang Construction and Production Corps, the paramilitary-cum-commercial organisation tasked by the CCP with developing Xinjiang's economy.

\section{Hidden linkages}

Beyond these clear linkages between FSG and Xinjiang, other plausible but less obvious connections link the company to the region and its camps. For example, since acquiring a stake in Beijing's International

"This essay was originally published in the Made in China Journal (vol. 4, no. 1, 2019), doi.org/ | 0.22459/MIC.04.0 I.20 19.0I. The article has been updated for inclusion in this volume. 
Security and Defence College in May 2017, FSG has been working to train private antiterrorism personnel in China (Martina 2017). And although no explicit links between the college and Xinjiang are apparent, its antiterrorist mandate makes these likely and fits a broader pattern in China of importing 'de-extremification' and counterextremism strategies from abroad (see Byler's Chapter 5 in this volume; and Doyon 2019).

In addition to working within the PRC, Prince and FSG are also following China's commercial interests abroad. The company has unambiguously positioned itself as a security provider for the BRI. For example, in December 2018, FSG obtained a licence to operate in Cambodia, which is an enthusiastic supporter of the BRI and a recent recipient of US\$600 million in aid from China (FSG 2018b; Mech 2019). And, as we will see below, FSG also began operations in Myanmar in 2019.

These connections highlight how not just FSG and Prince, but also the private paramilitary industry more generally act as conduits between state actors. So, we should not be surprised to learn that while FSG works for China, Prince is simultaneously attempting to exert influence on US policy. In 2016, he addressed then newly elected President Donald Trump in a South China Morning Post opinion piece, advocating for the United States to become involved with the BRI (Prince 2016).

But Prince has closer ties to Trump than your average op-ed writer. In addition to having donated a quarter of a million dollars to Trump's presidential campaign, Prince is also the brother of Trump's Secretary of Education, Betsy DeVos (Kirsch 2018). It should not be surprising, then, that in 2017 he met with members of the Trump administration to pitch the privatisation of US operations in Afghanistan and Syria (Hall 2019; Roston 2017). Tellingly, he refers to this strategy as an 'East India Company' approach and suggests it should be led by an 'American viceroy' (Prince 2017).

\section{The private paramilitary industry in Xinjiang}

So, Erik Prince is advocating for the United States to roll out mercantile colonialism from Afghanistan to Nigeria, while also helping to train antiterrorism personnel in the PRC, employing political elites from Xinjiang, and opening operations along the BRI. This entanglement of state and private interests across borders has important implications for how we think about, and act against, the Xinjiang camps. 
First, it makes clear that we should be paying more attention to private transnational actors - not just Prince and FSG, but also the entire private paramilitary industry. The Xinjiang camps are built and maintained not only by state colonialism, but also by transnational carceral capitalism (Wang 2018). What other connections exist between Xinjiang and security providers from outside the PRC?

Understanding this is important because it will shed light on what techniques are being exchanged and circulated between carceral institutions around the world. This might provide insights into what is going on in Xinjiang when we have such limited access to the realities of the camps.

Researchers have already learnt much about the Xinjiang camps by tracing their evolution from trials elsewhere inside the PRC. Adrian Zenz and James Leibold (2017) have shown how securitisation techniques road-tested in Tibet are now applied in Xinjiang. These include the so-called convenience policing system, which places police at regular intervals throughout the city to implement 'grid-style social management', as well as the practice of placing tens of thousands of CCP officials in villages to 'aid and assist' (and monitor) people (Leibold 2020). Sarah Cook (2019), meanwhile, has shown how the techniques of 'mental transformation' being used in Xinjiang were first tested on members of the Falun Gong.

But missing from this story of the internal circulation of methods and technologies of control within China is the exchange of these things transnationally. Take the camps themselves. We know that concentration camps as a carceral form were first deployed in Cuba by Spain during the Cuban War of Independence (1895-98) (Mühlhahn 2010) and achieved something like their current form under the British in South Africa during the Anglo-Boer War (1899-1902) (Forth 2017). They were then developed through their global circulation and iterative tweaking by a variety of states across the twentieth century (Stone 2017; Pitzer 2017) and obtained new legitimacy in the twenty-first century as a technology of 'carceral humanitarianism' (Oliver 2017).

So, we should be asking, beyond sources within the PRC, what are the transnational precursors to the Xinjiang camps? On what current models might the camps' architects be drawing? What role might private security and logistics companies play in linking these diverse examples, and accelerating the circulation of carceral expertise? 


\section{Across borders}

Given the way these technologies circulate transnationally, and considering FSG's role as a BRI private security force, we should be concerned with the possibility that camps might spread across borders. In February 2019, FSG began advertising to recruit security personnel in Myanmar and, a month later, registered the company name FSG (Myanmar) Security Services Company Limited (Chau 2019). At this time, Kachin nongovernmental organisation worker Doi Ra expressed concerns to Asia Times journalist Bertil Lintner (2019) about the potential role FSG might play in helping the state suppress resistance and force through unpopular infrastructure projects.

We know little about what FSG has been doing in Myanmar since then. However, in 2018, FSG listed news on its website about the memorandum of understanding that was signed in September of that year between Myanmar and the PRC to establish a transnational economic corridor (FSG 2018a). This corridor starts in Yunnan, where FSG has an office, and ends in the Kyaukphyu Special Economic Zone in Rakhine State, where the Myanmar Government carried out ethnic cleansing of Rohingya people in 2017, and where CITIC Group (Myanmar), part of the Chinese state-owned CITIC Group, is currently building a deep-sea port (AFP 2019). We need to worry about how PRC money and private paramilitary expertise might be used to 'help' nations along the BRI solve their domestic problems.

Beyond these concerns, the transnational privatisation of mass detention gives us two good reasons to be sceptical about the effectiveness of lobbying state actors to intervene in the Xinjiang camps. First, most major state players today have an interest in honing their carceral techniques and technologies, and private security firms enable liberal democracies to learn from authoritarian states, where the latitude for trial and error is much greater. In this regard, it is important to remember that it was claimed that President Trump encouraged Chinese President Xi Jinping to build the Xinjiang camps, describing it as 'exactly the right thing to do' (AFP and SBS News 2020). We should also note that since international outcry has been raised about the Xinjiang camps, India has begun building its own camp system to contain Indian residents who have been declared 'foreigners' (Pradhan 2020). Detention facilities thus have an uncanny transnational mobility. 
Second, although the BRI has become a source of geopolitical friction, such divisions are worn away by the flow of transnational capital, and the commercial stakes associated with the BRI are vast. It seems unlikely that any states will work against their own political and economic interests to intervene in Xinjiang.

Rather than lobbying states, a more effective strategy would be to address the struggle against the Xinjiang concentration camps to actors who have no vested interests in the camps being maintained: anticolonial, anticapitalist, and prison abolitionist movements. 
This text is taken from Xinjiang Year Zero, edited by Darren Byler, Ivan Franceschini and Nicholas Loubere, published 2022, The Australian National University, Canberra, Australia.

doi.org/10.22459/XYZ.2021.15 